The Agriculturists 18(1): 56-65 (2020) ISSN 2304-7321 (Online), ISSN 1729-5211 (Print)

A Scientific Journal of Krishi Foundation

Indexed Journal

DOI: https://doi.org/10.3329/agric.v18i1.49459

\title{
Physio-morphological Study of Betel Vine (Piper betle L.) Cultivars Available in Bangladesh
}

\author{
Md. Hafizur Rahman ${ }^{1}$, Md. Rafiqul Islam ${ }^{2}$, F. M. Aminuzzaman ${ }^{2}$, Abdul Latif $^{3}$ and \\ Habibur Rahman ${ }^{4}$ \\ ${ }^{1}$ Regional Agricultural Research Station, BARI, Cumilla, Bangladesh $;{ }^{2}$ Dept. of Plant Pathology and \\ ${ }^{3}$ Dept. of Entomology, Sher-e-Bangla Agricultural University, Dhaka, Bangladesh $;{ }^{4}$ Dept. of Plant \\ Pathology, Patuakhali Science and Technology University, Patuakhali, Bangladesh \\ *Corresponding author and Email: kbdmhrahman@gmail.com
}

Received: 23 September 2019

Accepted: 25 June 2020

\begin{abstract}
The experiment was conducted during March, 2016 to March, 2017 in a baroj of experimental farm of Sher-e-Bangla Agricultural University, Dhaka. Thirteen betel vine cultivars designated as PB 001 through PB 013 were collected from different locations of Bangladesh and found remarkable variations in vegetative growth, morphological features, yield and yield attributes. The betel vine cultivars varied in vine elongation $(37.46-50.34 \mathrm{~cm}$ per month), increase in internode length $(6.75-10.08 \mathrm{~cm}$ per month) and vine girth $(0.445-0.747 \mathrm{~cm}$ per year). The leaf length $(17.13-27.35 \mathrm{~cm})$, leaf breadth $(8.33$ - $16.20 \mathrm{~cm})$, petiole length $(4.83-11.45 \mathrm{~cm})$ and petiole breadth $(0.47-0.28 \mathrm{~cm})$ remarkably varied among the cultivars. Fresh weight of 100-petiole, 100-leaves, and dry matter content were 50.07 $165.74 \mathrm{~g}, 289.38-565.25 \mathrm{~g}$ and $12.57-14.49 \%$, respectively in different cultivars. Leaf number per meter vine $(9.46$ - 15.38) and leaf number per plant per year (50.16 - 78.44) were also varied among the cultivars. The highest annual per hectare yield was obtained from BARI Pan-1 (23.82 t) and PB $006(23.46 \mathrm{t})$. Variations were also existed among the cultivars in vine colour, leaf colour, leaf shape, leaf tip, leaf softness and pungency of leaf of cultivars. No pungency of leaf was found in cultivars PB 006 (Misti pan). So, PB 006 (Misti pan) was seemed to be a better cultivar/ germplasm in respect of yield and quality of betel leaf.
\end{abstract}

Keywords: Betel vine, morphological features, yield

\section{Introduction}

Betel vine (Piper betle L.), vernacularly known as Pan, is a kind of dioecious perennial creeper vine belonging to the family Piperaceae. It is cultivated largely for its leaves. It is an important cash crop of Bangladesh. Betel vine leaves possessed a strong pungent aromatic flavour and are widely used as masticatory. Mature leaves are used for chewing with smeared hydrated lime and catechu, areca nut, cardamom, clove, etc.
Chewing of betel leaf is considered as a good and cheap source of dietary calcium. Usually the people of South-Asia, South-east Asia, Gulf States and Pacific Islands chew betel leaves. All classes of people of Bangladesh chew betel leaves not only as a habit but also as an item of rituals, etiquette and manners. Morphologically betel leaves are shiny, broadly ovate and green heart-shaped with bleaching quality and softness. The stems are semi woody, climbing by many short adventitious roots. 
There are about 100 varieties of betel vine across the world out of which 30 varieties are being cultivating in the West Bengal and Bangladesh (Guha, 1997). A good number of betel vine cultivars viz., Desi Bangla, Bangla, Kali Bangla, Jhali, Sanchi, Goyeshi, Bhabna, Mitha, Geso, Bonhoogly, etc. are found in Bangladesh. The place of origin of betel vine is thought to be Malayasia (Chattapadhyay and Maity, 1967). In ancient times, pan (betel vine) was cultivated in all over Bengal, preferably in Dinajpur, Rangpur and Chittagong districts. Bangladesh exports betel leaves to many countries of Asia and Europe especially India, Pakistan, Saudi Arabia, United Arab Emirates, England, Italy and Germany. Export quality betel leaves are presently grown in the districts of Natore, Kushtia, Rajshahi, Barisal, Khulna and Chuadanga.

Total cultivated area under the crop in Bangladesh in 2016-17 was about 23803.20 hectares and the total annual production was about 214252 metric tons. The average yield per hectare is 9.0 metric tons (BBS, 2018). Pan leaf is usually plucked throughout the year but maximum production obtained during the months of July through October. To maximize betel leaf production in the country it is essential to find out better land races or germplasm for development of high yielding variety of the crop. From the above facts, the present investigation was undertaken to screen out suitable cultivars/germplasm for better yield and quality of betel leaf in the country.

\section{Materials and Methods}

The experiment was conducted during March, 2016 to March, 2017. A total of 13 betel vine cultivars were collected from different betel vine growing areas of Bangladesh (Table 1; Plate 1).

Apparently healthy vines of different betel vine cultivars/variety were used to prepare cuttings. The experiment was conducted in-vivo in earthen pots placed in betel vine baroj. About $40 \mathrm{~cm}$ long cutting with five nodes were grown singly in 14 inches diameter earthen pot. The pots were placed inside a baroj of experimental farm of Sher-e-Bangla Agricultural University (SAU), Dhaka and allowed to grow with necessary care and management. Potting medium was prepared by mixing soil, sand and well decomposed cowdung in a proportion of $2: 1: 1$ and were sterilized by formaldehyde.

Table 1. Particulars of the betel vine cultivars collected from different locations of Bangladesh

\begin{tabular}{lll}
\hline Accession No. & Name of Cultivars & Location of collection (Upazilla and District) \\
\hline PB 001 & Laldingi pan & Pakundia, Kishoregonj \\
PB 002 & BARI Line & Spices Research Centre, BARI, Bogura \\
PB 003 & Chalitaguti pan & Gouronadi, Barisal \\
PB 004 & Sanchi pan & Kaligonj, Jhenaidah \\
PB 005 & BARI Line & Spices Research Centre, BARI, Bogura \\
PB 006 & Misti pan & Mohanpur, Rajshahi \\
PB 007 & BARI Line & Spices Research Centre, BARI, Bogura \\
PB 008 & BARI Line & Spices Research Centre, BARI, Bogura \\
PB 009 & BARI Pan -1 & RARS, Barisal \\
PB 010 & Bangla pan & Mirpur, Kushtia \\
PB 011 & Jhal pan & Sitakunda, Chittagong \\
PB 012 & Bhabna pan & Kaligonj, Jhenaidah \\
PB 013 & Gayasur pan & Pakundia, Kishoregonj \\
\hline
\end{tabular}




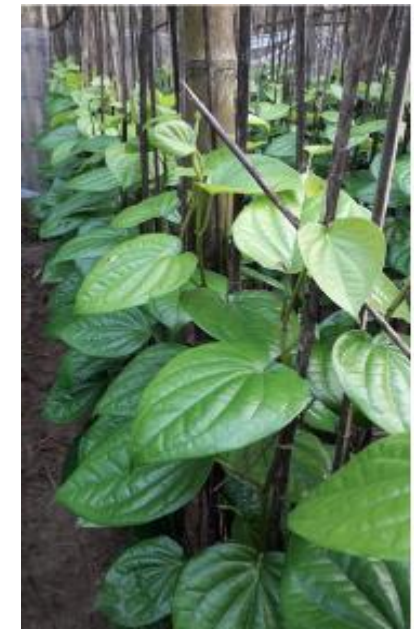

PB 001 (Laldingi pan)

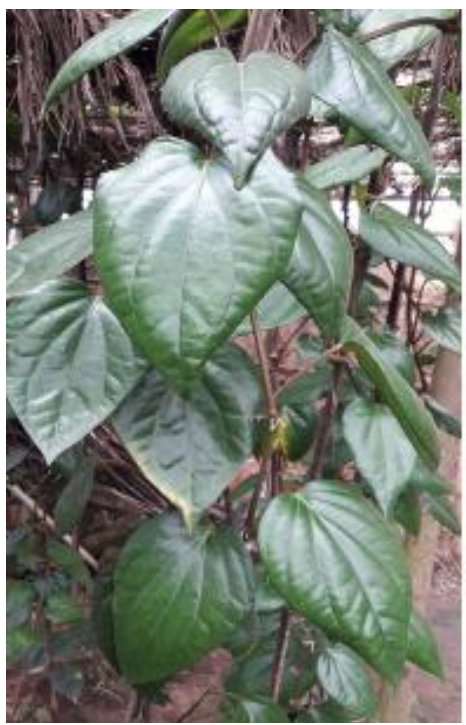

PB 004 (Sanchi pan)

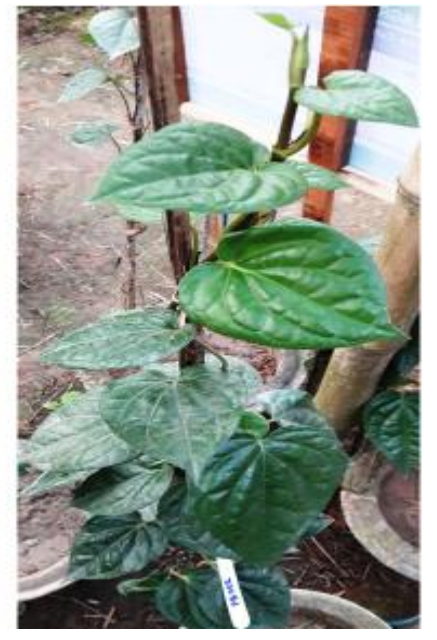

PB 002 (BARI line)

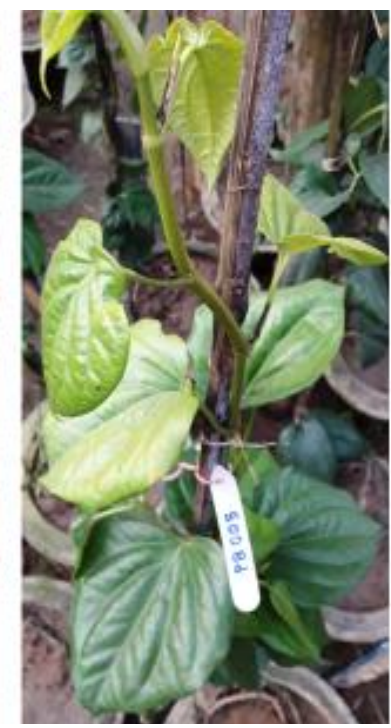

PB 005 (BARI line)

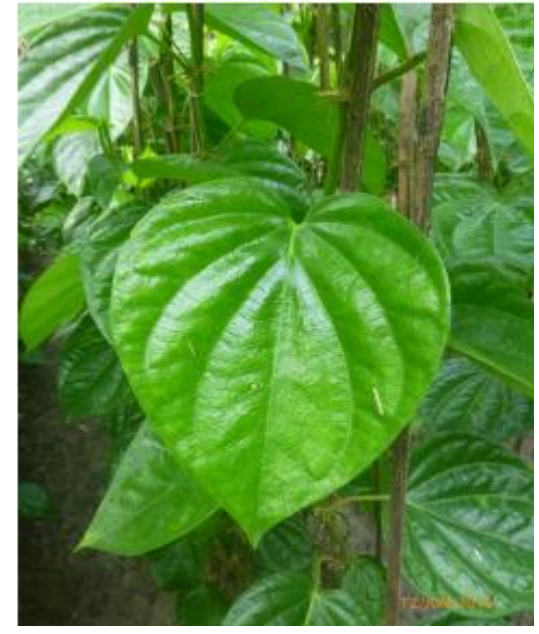

PB 003 (Chalitaguti pan)

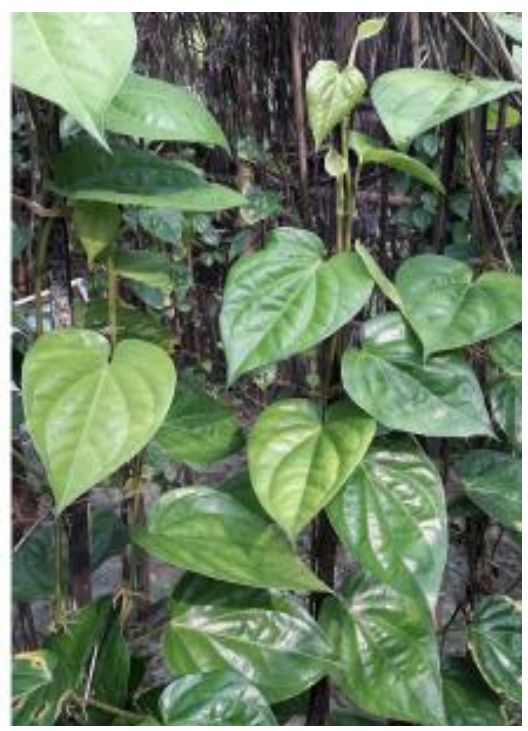

PB 006 (Misti pan)

Plate 1. Morphological variations of leaves in different betelvine cultivars 


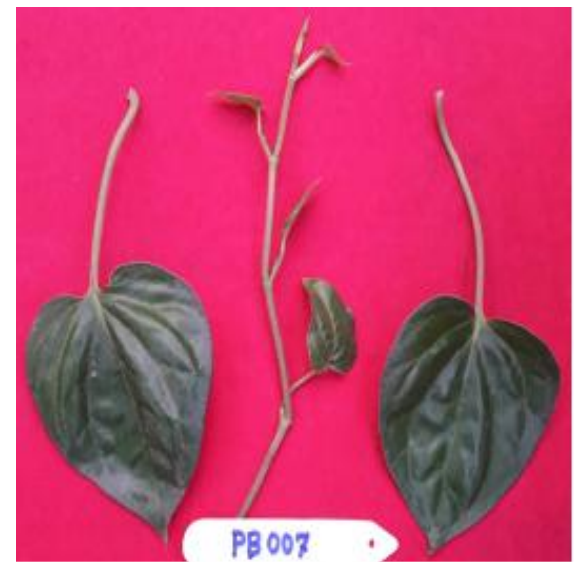

PB 007 (BARI line)

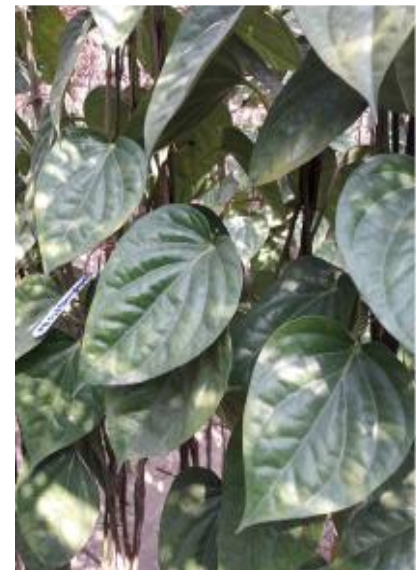

PB 010 (Bangla pan)

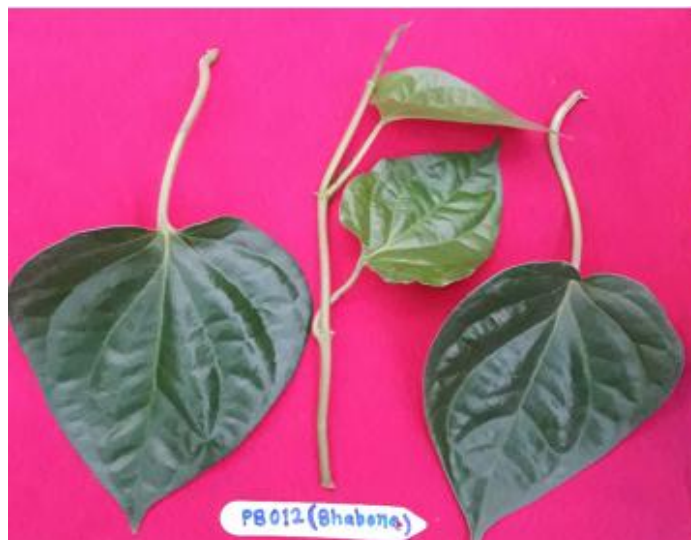

PB 012 (Bhabna pan)

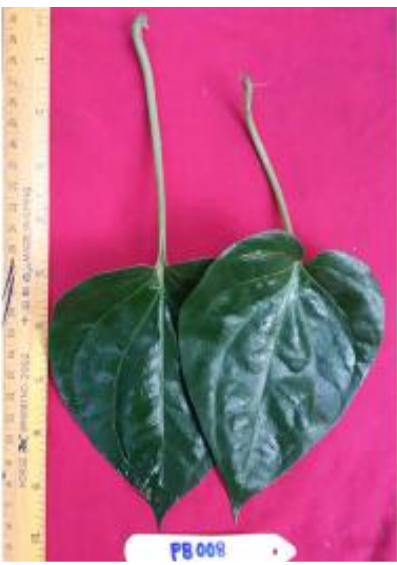

PB 008 (BARI line)

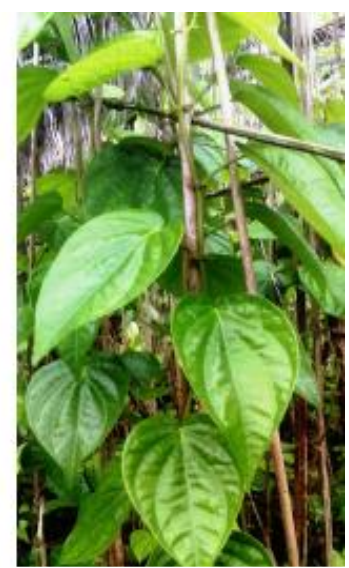

PB 009 (BARI Pan - 1)

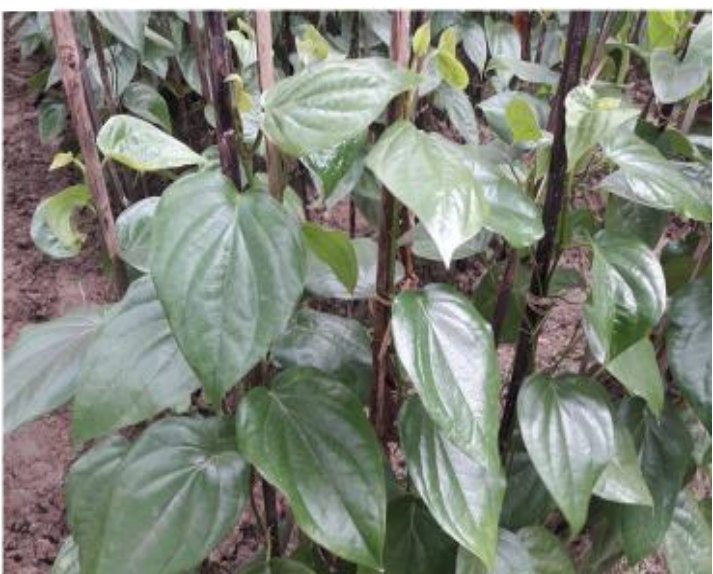

PB 011 (Jhal pan)

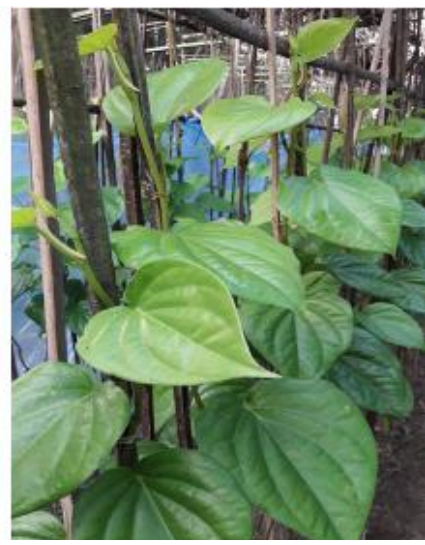

PB 013 (Gayasur pan)

Plate 1 (Continued). Morphological variations of leaves in different betelvine cultivars 
Formalin solution (4\%) @ $200 \mathrm{ml} / \mathrm{cft}$ soil was mixed with the soil heap and the soil was covered with a polythene sheet for 48 hours and kept uncovered for 7 days. After 7 days, the surface sterilized earthen pots were filled with sterilized soil (Dashgupta, 1988). One to two internodes below the bud point were dipped into the soil and the vine fastened with bamboo sticks of baroj. The experiment was laid out in a randomized complete block design (RCBD) with 4 replications. Data were recorded on vegetative growth, yield and yield attributing parameters of betel vine. The data were statistically analyzed by a computer package "Statistix 10". Duncan's multiple range test (DMRT) was done for comparison of various treatment means (Gomez and Gomez, 1983).

\section{Results and Discussion}

\subsection{Vegetative growth parameters of betel vine cultivars}

The vegetative growth parameters and morphological features of different germplasm of betel vine varied remarkably (Table 2). The vine elongation in different cultivars of betel vine ranged from 37.46 to $50.34 \mathrm{~cm} /$ month. Maximum vine increment of $50.34 \mathrm{~cm}$ per month was recorded in PB 005 followed by PB 006, PB 003 and PB 012. The lowest vine increment of $37.46 \mathrm{~cm}$ was recorded in PB 008. Increase in internode length per month ranged from 6.75$10.08 \mathrm{~cm}$ in different cultivars. The highest length of internode was recorded from PB 004 that was statistically similar to PB 006 and the minimum length was found in PB 007 and PB 013 .

The vine girth of different betel vine cultivars varied from 0.445 to $0.747 \mathrm{~cm}$. Maximum vine girth was recorded in PB 005 while the minimum vine girth was found in PB 012 followed by PB 002 and PB 013. Leaf length of various cultivars was 17.13 to $27.35 \mathrm{~cm}$. The highest length of leaf was recorded from PB 012, which was statistically similar to PB 003, 004, 009 and 010. The lowest leaf length was recorded in PB 013 . The leaf breadth in different cultivar was 8.33 to
$16.20 \mathrm{~cm}$. The highest leaf breadth was recorded from PB $004(16.20 \mathrm{~cm})$ and the lowest from PB $007(8.33 \mathrm{~cm})$. The length of petiole was the highest in PB $010(11.45 \mathrm{~cm})$ which was statistically similar to PB 007 and PB 009. The lowest length of petiole was recorded in PB 013 $(4.83 \mathrm{~cm})$. The maximum petiole breadth was found in PB $004(0.47 \mathrm{~cm})$ and the lowest in PB $007(0.28 \mathrm{~cm})$.

Pariari and Imam (2012a) observed maximum vine length $(48.40 \mathrm{~cm})$ in Simurali Sanchi which was at par with Simurali Deshi $(48.01 \mathrm{~cm})$ and Simurali Bhabna $(45.91 \mathrm{~cm})$ and also the shortest internode in the cultivar Jabalpur $(3.38 \mathrm{~cm})$. Longer vine with shorter internode is a desirable character in betel vine that produced comparatively more number of leaves. The longest leaf $(16.73 \mathrm{~cm})$ was recorded in Ghanagette, which was statistically at par with Simurali Sanchi $(16.71 \mathrm{~cm})$, Simurali Jhal (16.43 $\mathrm{cm})$, CARI-2 $(15.75 \mathrm{~cm})$, CARI-6 $(15.33 \mathrm{~cm})$ and Sanchi $(14.75 \mathrm{~cm})$. Leaf width between 4.20 $\mathrm{cm}$ and $11.60 \mathrm{~cm}$ was reported by Rahaman et al. (1997) from a study with 27 genotypes of betel vine.

Pariari and Imam (2012b) conducted an investigation on betel vine and the result indicated that leaf width ranged from 8.65 $10.45 \mathrm{~cm}$ which was supported to present investigation. Reddy (1996) reported that petiole length of betel leaves varied $(5.2-6.6 \mathrm{~cm})$ significantly among cultivars though Chaveerach et al. (2006) reported $2.0-2.5 \mathrm{~cm}$ length of petiole.

\subsection{Yield and yield contributing characters of different betel vine cultivars}

The yield and yield contributing characters varied significantly among the betel vine cultivars (Table 3 ). The weight of 100 petiole of betel leaf was found highest in PB 010 (165.74 g) followed by PB 012 and the lowest weight in PB 013 (46.38 g). The maximum fresh weight $(565.03 \mathrm{~g})$ of 100 leaves with petiole was recorded from PB 009 followed by PB 008 and the lowest from PB 007 (264.38 g). 
Table 2. Variations in vegetative growth parameters of different betel vine cultivars grown in earthen pot under betel vine baroj condition

\begin{tabular}{|c|c|c|c|c|c|c|c|}
\hline \multirow[b]{2}{*}{ Betel vine cultivars } & \multirow{2}{*}{$\begin{array}{c}\text { Vine } \\
\text { elongation/ } \\
\text { Month (cm) }\end{array}$} & \multirow{2}{*}{$\begin{array}{l}\text { Length of } \\
\text { internode } \\
\text { (cm) }\end{array}$} & \multirow{2}{*}{$\begin{array}{l}\text { Girth of } \\
\text { vine } \\
(\mathrm{cm})\end{array}$} & \multicolumn{2}{|c|}{ Leaf size with petiole $(\mathrm{cm})$} & \multicolumn{2}{|c|}{ Petiole size $(\mathrm{cm})$} \\
\hline & & & & Length & Breadth & Length & Breadth \\
\hline PB 001(Laldingi pan) & $38.77 \mathrm{de}^{*}$ & $8.43 \mathrm{bc}$ & $0.5775 \mathrm{~d}$ & $22.81 \mathrm{ef}$ & $12.95 \mathrm{~b}-\mathrm{d}$ & $7.45 \mathrm{c}-\mathrm{e}$ & $0.35 \mathrm{~b}-\mathrm{e}$ \\
\hline PB 002(BARI line) & $37.86 \mathrm{e}$ & $7.15 \mathrm{de}$ & $0.4538 \mathrm{fg}$ & $19.60 \mathrm{~g}$ & $9.33 \mathrm{ef}$ & $7.95 \mathrm{c}-\mathrm{e}$ & 0.30 ef \\
\hline PB 003 (Chalitaguti pan) & $43.17 \mathrm{bc}$ & $7.50 \mathrm{de}$ & $0.5325 \mathrm{de}$ & $25.65 \mathrm{a}-\mathrm{d}$ & $14.35 \mathrm{~b}$ & $8.70 \mathrm{~b}-\mathrm{d}$ & $0.37 \mathrm{~b}-\mathrm{d}$ \\
\hline PB 004(Sanchi pan) & $41.91 \mathrm{c}$ & $10.08 \mathrm{a}$ & $0.6500 \mathrm{bc}$ & $26.23 \mathrm{a}-\mathrm{c}$ & $16.20 \mathrm{a}$ & $6.98 \mathrm{de}$ & $0.47 \mathrm{a}$ \\
\hline PB 005 (BARI line) & $50.34 \mathrm{a}$ & $7.73 \mathrm{~cd}$ & $0.7475 \mathrm{a}$ & $22.60 \mathrm{ef}$ & $12.93 \mathrm{~b}-\mathrm{d}$ & $8.75 \mathrm{bc}$ & $0.39 \mathrm{~b}$ \\
\hline PB 006 (Misti pan) & $44.86 \mathrm{~b}$ & $9.38 \mathrm{a}$ & $0.5925 \mathrm{~cd}$ & $24.80 \mathrm{~cd}$ & $13.50 \mathrm{~b}-\mathrm{d}$ & $9.98 \mathrm{ab}$ & $0.33 \mathrm{c}-\mathrm{f}$ \\
\hline PB 007 (BARI line) & $41.01 \mathrm{~cd}$ & $6.75 \mathrm{e}$ & $0.5150 \mathrm{ef}$ & $21.35 \mathrm{fg}$ & $8.33 \mathrm{f}$ & $10.95 \mathrm{a}$ & $0.28 \mathrm{f}$ \\
\hline PB 008 (BARI line) & $37.46 \mathrm{e}$ & $8.33 \mathrm{bc}$ & $0.6575 \mathrm{~b}$ & $24.00 \mathrm{de}$ & $12.15 \mathrm{~d}$ & $10.38 \mathrm{ab}$ & $0.38 \mathrm{bc}$ \\
\hline PB 009 (BARI Pan-1) (Control) & $37.53 \mathrm{e}$ & $8.55 \mathrm{~b}$ & $0.5400 \mathrm{de}$ & $25.63 \mathrm{a}-\mathrm{d}$ & $12.25 \mathrm{~cd}$ & $11.23 \mathrm{a}$ & $0.33 \mathrm{~b}-\mathrm{f}$ \\
\hline PB 010 (Bangla pan) & $41.37 \mathrm{c}$ & $8.45 \mathrm{bc}$ & $0.6775 \mathrm{~b}$ & $27.03 \mathrm{ab}$ & $12.85 \mathrm{~b}-\mathrm{d}$ & $11.45 \mathrm{a}$ & $0.37 \mathrm{~b}-\mathrm{d}$ \\
\hline PB 011 (Jhal pan) & $38.36 \mathrm{e}$ & $7.05 \mathrm{de}$ & $0.5600 \mathrm{de}$ & $25.58 \mathrm{~b}-\mathrm{d}$ & $14.35 \mathrm{~b}$ & $6.65 \mathrm{e}$ & $0.32 \mathrm{~d}-\mathrm{f}$ \\
\hline PB 012 (Bhabna pan) & $42.42 \mathrm{c}$ & $7.33 \mathrm{de}$ & $0.4450 \mathrm{~g}$ & $27.35 \mathrm{a}$ & $13.85 \mathrm{bc}$ & $10.43 \mathrm{ab}$ & $0.39 \mathrm{~b}$ \\
\hline PB 013(Gayasur pan) & $37.47 \mathrm{e}$ & $6.75 \mathrm{e}$ & $0.4700 \mathrm{fg}$ & $17.55 \mathrm{~h}$ & $10.28 \mathrm{e}$ & $4.83 \mathrm{f}$ & $0.38 \mathrm{~b}-\mathrm{d}$ \\
\hline
\end{tabular}

*Values within the same column with a common letter(s) did not differ significantly $(P \leq 0.01)$. 
Table 3. Yield and yield contributing characters of different betel vine cultivars grown in earthen pot under betel vine baroj condition

\begin{tabular}{|c|c|c|c|c|c|c|c|}
\hline Betel vine cultivars & $\begin{array}{l}100 \\
\text { Petiole } \\
\text { wt. (g) }\end{array}$ & $\begin{array}{l}\text { Fresh wt. of } \\
100 \text { leaf } \\
\text { (g) }\end{array}$ & Dry matter (\%) & $\begin{array}{l}\text { Leaf/meter } \\
\text { vine } \\
\text { (no.) }\end{array}$ & $\begin{array}{l}\text { Leaf / } \\
\text { plant/year } \\
\text { (no.) }\end{array}$ & $\begin{array}{l}\text { Yield/ } \\
\text { plant/year } \\
\text { (g) }\end{array}$ & $\begin{array}{l}\text { Yield/ } \\
\text { year) } \\
\text { (t/ha) }\end{array}$ \\
\hline PB 001(Laldingi pan) & $5.12 \mathrm{i}^{*}$ & $515.50 \mathrm{~b}$ & $14.14 \mathrm{ab}(21.30)$ & $11.07 \mathrm{c}-\mathrm{e}$ & $55.19 \mathrm{~d}-\mathrm{f}$ & $284.54 a-c$ & $22.76 a-c$ \\
\hline PB 002 (BARI Line) & $57.07 \mathrm{j}$ & $289.38 \mathrm{~g}$ & $13.83 a-c(21.03)$ & $12.81 \mathrm{~b}$ & $64.92 \mathrm{c}$ & $187.89 \mathrm{f}$ & $15.03 \mathrm{f}$ \\
\hline PB 003 (Chalitaguti) & $103.55 f$ & $317.05 f$ & $14.26 \mathrm{ab}(21.40)$ & $12.41 \mathrm{bc}$ & $69.39 \mathrm{bc}$ & $220.09 \mathrm{e}$ & $17.61 \mathrm{e}$ \\
\hline PB 004 (Sanchi pan) & $122.95 d$ & $445.00 \mathrm{c}$ & $13.06 a-c(20.42)$ & $9.46 f$ & $50.16 \mathrm{f}$ & $223.07 \mathrm{e}$ & $17.85 \mathrm{e}$ \\
\hline PB 005 (BARI Line) & $128.77 \mathrm{c}$ & $346.20 \mathrm{e}$ & $13.83 \mathrm{a}-\mathrm{c}(21.05)$ & $12.74 b$ & $78.44 \mathrm{a}$ & $272.11 \mathrm{c}$ & $21.77 \mathrm{c}$ \\
\hline PB 006 (Misti pan) & $130.82 \mathrm{c}$ & $515.25 b$ & $13.31 \mathrm{a}-\mathrm{c}(20.63)$ & $10.05 \mathrm{ef}$ & $57.71 \mathrm{de}$ & $297.12 \mathrm{a}$ & $23.77 \mathrm{a}$ \\
\hline PB 007 (BARI Line) & $86.54 \mathrm{~g}$ & $264.38 \mathrm{~h}$ & $14.49 \mathrm{a}(21.51)$ & $15.38 \mathrm{a}$ & $73.05 \mathrm{ab}$ & $193.19 f$ & $15.46 f$ \\
\hline PB 008 (BARI Line) & $130.15 \mathrm{c}$ & $544.13 \mathrm{a}$ & $12.80 \mathrm{bc}(20.21)$ & $12.05 \mathrm{~b}-\mathrm{d}$ & $54.16 \mathrm{~d}-\mathrm{f}$ & $293.21 \mathrm{ab}$ & $23.46 \mathrm{ab}$ \\
\hline PB 010 (Bangla pan) & $165.74 \mathrm{a}$ & $416.25 d$ & $12.28 \mathrm{c}(20.21)$ & $11.22 \mathrm{c}-\mathrm{e}$ & $58.98 \mathrm{~d}$ & $245.51 \mathrm{~d}$ & $19.64 d$ \\
\hline PB 011 (Jhal pan) & $77.02 \mathrm{~h}$ & $408.03 d$ & $14.35 \mathrm{ab}(19.77)$ & $13.35 b$ & $65.89 \mathrm{c}$ & $268.51 \mathrm{c}$ & $21.48 \mathrm{c}$ \\
\hline PB 012 (Bhabna pan) & $148.38 b$ & $313.25 \mathrm{f}$ & $12.57 \mathrm{c}(21.47)$ & $13.20 \mathrm{~b}$ & $70.70 \mathrm{bc}$ & $221.66 \mathrm{e}$ & $17.73 \mathrm{e}$ \\
\hline PB 013 (Gayasur pan) & $46.38 \mathrm{k}$ & $411.00 \mathrm{~d}$ & $13.27 \mathrm{a}-\mathrm{c}(20.03)$ & $16.35 \mathrm{a}$ & $66.59 \mathrm{c}$ & $273.69 b c$ & $21.89 \mathrm{bc}$ \\
\hline PB 009 (BARI Pan-1) (Control) & $114.90 \mathrm{e}$ & $565.03 \mathrm{a}$ & $12.79 b c(20.59)$ & $10.72 d-f$ & 52.70 ef & $297.78 \mathrm{a}$ & $23.82 \mathrm{a}$ \\
\hline
\end{tabular}

*Values within the same column with a common letter(s) did not differ significantly $(P \leq 0.01)$.

Data within parenthesis are arc-sine transformed values. 
Table 4. Physio-morphological characters of betel vine cultivars grown in orchard (Pan baroj) at SAU campus

\begin{tabular}{|c|c|c|c|c|c|c|}
\hline Betel vine cultivars & Vine colour & Leaf colour & Leaf shape & Leaf tip & $\begin{array}{l}\text { Leaf } \\
\text { softness }\end{array}$ & Pungency of leaf \\
\hline PB 001 (Laldingi pan) & Green & Green & Cordate & Acute & less soft & Medium pungent \\
\hline PB 002 (BARI Line) & Violet & Dark green & Cordate & Acute & Leaf soft & Less pungent \\
\hline PB 003(Chalitaguti pan) & Greenish with light pinkish line & Green & Cordate & Acute & Leaf soft & Less pungent \\
\hline PB 004(Sanchi pan) & Violet & Dark green & Cordate to ovate & Acute & Leaf soft & Pungent aroma \\
\hline PB 005 (BARI Line) & Greenish with light pinkish line & Dark green & Cordate & Acute & Leaf soft & Highly pungent \\
\hline PB 006(Misti pan) & Dark green & Green & Cordate & Acute & Leaf soft & No pungent \\
\hline PB 007 (BARI Line) & Violet & Dark green & Cordate & Acute & Leaf soft & Medium pungent \\
\hline PB 008(BARI Line) & Violet & Dark green & Cordate & Acute & Leaf soft & Medium pungent \\
\hline PB 010 (Bangla pan) & Green & Dark green & Cordate & Acute & Leaf soft & Medium pungent \\
\hline PB 011 (Jhal pan) & Dark green & Light green & Cordate & Acute & Leaf soft & Highly pungent \\
\hline PB 012 (Bhabna pan) & Greenish with pinkish line & Dark green & Cordate & Acute & Leaf soft & Less pungent \\
\hline PB 013 (Gayasur pan) & Green & Light green & Cordate & Acute & Leaf soft & Less pungent \\
\hline PB 009 (BARI Pan -1) & Green & Light green & Cordate to ovate & Acum-inate & Leaf soft & Medium pungent \\
\hline
\end{tabular}


The highest dry matter (14.49\%) content was recorded from cultivar PB 007 followed by $\mathrm{PB}$ 002, PB 011 and PB 001 and the lowest from PB $010(12.28 \%)$ and PB 012. The PB 013 produced significantly highest number of leaves (16.35 no.) per meter vine followed by PB 007 and the lowest number (9.46 no.) of leaves per meter vine was recorded from PB 004. Leaf number per plant per year was found the highest in $\mathrm{PB}$ 005 (78.44 no.) and the lowest from PB 004 (50.16 no.). The highest yield per plant annually was obtained from PB 009 followed by PB 006 and the lowest yield per plant per year was recorded from PB 002 followed by PB 007. The highest annual yield (23.82 ton) per hectare was obtained from PB 009 followed by PB 006 and the lowest annual yield (15.03 ton) was from $\mathrm{PB}$ 002 followed by PB 007 (Table 3).

Das et al. (1995) found maximum fresh weight $(380.75 \mathrm{~g})$ and dry weight $(44.60 \mathrm{~g})$ in Ghanagette cultivar and produced highest number of leaves (88) per vine. Guha (2006) reported that annual yield of a good crop of betel vine was $60-70$ leaves/ plant and $6-7$ millions/ha. Similarly Pariari and Imam (2012a) found significant variation among different cultivars and Simurali Deshi produced maximum number of leaves (58.56/vine), and minimum (37.63/vine) by Simurali Jhal.

\subsection{Morphological features of the betel vine cultivars}

The betel vine cultivars varied remarkably in morphological characteristics viz. vine colour, leaf colour, leaf shape and tip, leaf softness and pungency (Table 4).

\subsubsection{Vine colour}

The vine colour of different betel vine cultivars was observed as dark green, green, greenish with light pinkish line, greenish with pinkish line and violet. The prevailing colours were dark green PB 006(Misti pan) and PB 011 (Jhal pan); green PB 001 (Laldingi pan), PB 010 (Bangla pan), PB 013 (Gayasur pan) and PB 009 (BARI Pan -1); greenish with light pinkish line $P B$
003(Chalitaguti pan) and PB 005 (BARI Line); greenish with pinkish line PB 012 (Bhabna pan); violet PB 002 (BARI Line), PB 004(Sanchi pan), PB 007 (BARI Line) and PB 008(BARI Line).

\subsubsection{Leaf color}

The evaluation of eleven betel vine cultivars in Bangladesh revealed that PB 001, PB 003, PB 006 had green leaves while PB 011, PB 009, PB 013 had light green and PB 002, PB 004, PB 005, PB 007, PB 008, PB 010, PB 012 had dark green coloured leaves (Table 4). Lakshmi and Naidu (2010) reported most of the varieties under study had dark green leaves except Kapoori which had light green leaf. Yellowish green to green coloured leaves were found in Sri Lanka (Preethy et al., 2016). Similar observations were reported in a study conducted by Joseph (1990) in Kerala.

\subsubsection{Leaf shape and tip}

The leaf shape of the 13 betel vine cultivars were cordate to ovate. All most of the cultivars were cordate leaf shape but PB 004 and PB 009 were cordate to ovate shape leaves. The apex of betel leaf was acute to acuminate. All the cultivars were acute tip except PB 009 which was acuminate type leaf tip (Table 4). This result supported by Chaveerach et al. (2006) who observed ovate to cordate leaf shape in $P$. betle and indicated that leaf apex was acuminate in betel vine. Lakshmi and Naidu (2010) indicated that among the 10 studied cultivars, seven cultivars showed acute type of leaf tip.

\subsubsection{Leaf softness and pungency}

Variation was found in softness and pungency of betel leaf. Only PB 001 was found less soft leaf of the evaluated cultivars/germplasm. Less pungent to highly pungent leaf was found in the different cultivars/germplasm. No pungent leaf was found in PB 006 but less pungent leaf was found in PB 002, PB 003, PB 012, PB 013 and medium pungent was found in $\mathrm{PB} 001, \mathrm{~PB} 007$, PB 008, PB 010, Pb 009 and rest of PB 004, PB 005 and PB011 were highly pungent leaves. 


\section{Conclusions}

Variation was existed among 13 betel vine cultivars in terms of growth, yield, and yield attributes. The cultivar PB 006 (Misti pan) and PB 009 (BARI Pan-1) produced significantly higher yield as $23.77 \mathrm{t} / \mathrm{ha}$ and $23.82 \mathrm{t} / \mathrm{ha}$, respectively. No pungency of leaf was found in the cultivar PB 006 (Misti pan) which seemed to be better germplasm for yield and quality though the cultivar PB 005 was better in respect of highest leaf number (78.44) and dry matter $(13.83 \%)$ production.

\section{References}

BBS. 2018. Year Book of Agricultural Statistics of Bangladesh-2017, 29 ${ }^{\text {th }}$ Series. Bangladesh Bureau of Statistics, Statistics and Informatics Division, Ministry of Planning, Government of the Peoples' Republic of Bangladesh. 197p.

Chattapadhyay SP., Maity S. 1967. Diseases of Betelvine and species. ICAR, New Delhi, India.

Chaveerach A., Mokkamul P., Sudmoon R., Tanee T. 2006. Ethnobotany of the genus Piper (Piperaceae) in Thailand. J. Pl. Peo. App. Res., 4: 223-231.

Das J.N., Das S.C., Mohanty C.R., Nayak B.B. 1995. Relative performance of some Bangla varieties of betel vine at Bhubaneswar. Orissa J. Hort., 23: 104107.

Dashgupta M.K. 1988. Principles of Plant Pathology. Allied Publisher Private Limited. New Delhi, India. 700p.
Gomez K.A., Gomez A.A. 1983. Statistical Procedures for Agril. Res. 2nd End. International Rice Research Institute, Manila, Philippines. Pp. 139-207.

Guha P. 2006. Betel leaf: The neglected green gold of India. J. . Human Eco., 19: 87-93.

Guha P., Jain R.K. 1997. Status Report on Production, Processing and Marketing of Betel Leaf (Piper betle L.). Agricultural and Food Engineering Department, IIT, Kharagpur, India. pp. 15-22.

Joseph K. 1990. Karyomorphological analysis in piperaceae. J.K Publications, Ernakulum. $13 \mathrm{p}$.

Lakshmi BS., Naidu KC. 2010. Comparative morphoanatomy of $P$. betle L. cultivars in India. Ann. Bio. Res., 2: 128-134.

Pariari A., Imam M.N. 2012a. Evaluation of betel vine (Piper betle L.) cultivars in the gangetic alluvial plains of West Bengal. Indian J. . Spi. Arom. Crops, 21(1): 0108 .

Pariari A., Imam MN. 2012b. Leaf characters of betelvine (Piper betle L.) as influenced nitrogen application. Indian J. Hort., 69(4): 573-577.

Preethy T.T., Aswathi K.K., Renisha J.M., Asha V.P. 2016. Spectrum of variation in land races and different morphological characters of betel vine. International $J$. Curr. Res., 8(03): 28164-28170.

Rahaman M., Das N.D., Jana S.C. 1997. Phenotypic stability for yield and yield attributes in betel vine (Piper betle L.). J. Plan. Crops, 25: 189-192.

Reddy M.L.N. 1996. Morphological variations in betel vine (Piper betle L.). J. Plan. Crops, 24: 115-118. 